(iv) to publish and assist the publication of the results of scholarly research in this field;

(v) to offer grants for research in this field, whenever practicable and desirable;

(vi) to establish association or affiliation with any other recognized scholarly association or international body as may seem desirable, and in particular with the International Council for Philosophy and the Humanistic Sciences, thereby entering into official relationship with UNESCO.

The Society expects to take over and develop most of the activities begun by the West African Languages Survey, including the organization of the annual Congress of West African Languages.

Professor Joseph H. Greenberg, the Chairman of the West African Languages Survey, is to be Chairman of the Council of the Society. Dr. Ayo Bamgboșe, of the University of Ibadan, is the Society's Secretary-Treasurer. The other members of the Council are: Professor Robert G. Armstrong, Institute of African Studies, Ibadan; Professor Maurice Houis, Centre National de la Recherche Scientifique, and formerly of IFAN, Dakar; Dr. M. Bot ba Njock, Université Fédérale du Cameroun, Yaoundé; Mr. Gilbert Ansre, Institute of African Studies, Ghana, and at present at SOAS, London; Professor Eldred Jones, University College of Sierra Leone; Dr. Bakary Coulibaly, École Normale de Ouagadougou, Haute-Volta; Professor Serge Sauvageot, Université de Dakar.

(Communicated by Mr. John Spencer)

\title{
International Congress of Bantu Linguists
}

M. ANDRÉ JACQUOT, who is in charge of language research at ORSTOM, would welcome exploratory discussions with those likely to be interested in an International Congress of Bantu Linguists, to be held at Brazzaville in July 1967 , organized by the Centre d'Enseignement Supérieur. By 1967 the latter institution will have been set up as an autonomous university. The question of language classification, which may lead to a re-evaluation of the nature of relationships between Bantu and other language families, is likely to be raised at the congress, and topics of interest to other specialists, such as comparative philology, socio-linguistics, Bantu literature, etc., could also be included. The programme for the meetings will depend largely on indications furnished by intending participants, who should communicate at their earliest convenience with M. Jacquot at ORSTOM, B.P. I8 I, Brazzaville, Congo.

\section{Symposium on African Art: Columbia University, New York}

ON Is May 1965 a symposium on 'The Aristocratic Traditions in African Art' was convened under the sponsorship of the Department of Art History and the Institute of African Studies, Columbia University, New York. Some fifty art historians, anthropologists, and museum curators met to hear and discuss six papers on aspects of the courtly or aristocratic styles in Africa, under the chairmanship of Professor Paul S. Wingert. Speakers included Daniel Biebuyck of the University of California, Los Angeles, formerly of Lovanium University, on the functions of art among the highest (or Kindi) grade members of the Bwami society of the Lega (Warega) of eastern Congo, and Roy Sieber of Indiana University on the meaning and history of funerary terracottas among the Kwahu of Ghana. Robert F. Thompson of Yale contrasted certain aristocratic elements in Yoruba art with others believed to be deliberately anti-aesthetic. Two groups of aristocratic art forms found in Iboland, the one indigenous, the other borrowed from Benin, were interpreted by Herbert M. Cole of Columbia University. Suzanne Rudy of Douglass College, Rutgers 